\title{
1 The theoretical dimension of the EU impact on Turkish counter-terrorism policy
}

Diffusion of the EU-promoted democratic norms towards third countries in its neighbourhood is not easy for EU actors. There are many internal and external dynamics that need to be taken into consideration, both by the EU and third-country political actors, in this challenging process. Due to each country in question having a different strategic culture, the EU has different mechanisms to exert influence over third countries in its neighbourhood. These mechanisms vary according to the interaction between the EU and the target country, and there is no one-size-fits-all solution that is applicable to every neighbouring country. For instance, those diffusion mechanisms valid for Turkey, which has candidate status, are not valid for the quasi-member countries such as Norway and Switzerland or Russia, which have symmetrical relations with the EU, while the ENP countries have no membership expectations. Therefore, examining the EU influence on Turkey necessitates focusing on the norm diffusion mechanisms that relate to the enlargement framework.

Turkey's long-standing ambition to join the EU, and the membership conditions for Turkey laid down by the EU, have ensured a political environment in which the EU can influence the domestic policies of Turkey. Rule adoption has sometimes been conditional, i.e. when Turkish political actors have transposed EU rules conditional on there being a prospect of EU membership, customs union, or visa liberalization agreement. At other times, it has been based on sociological reasons, e.g. when Turkish political actors have considered EU-promoted norms to be appropriate for solving domestic problems. In view of these examples, two EU norm diffusion mechanisms, 'conditionality' and 'socialization', come to the forefront when attempting to explain the EU influence on Turkey. These two EU mechanisms are based theoretically on 'New Institutionalism', which is the primary framework in contemporary Europeanization studies. According to March and Olsen, an 'institution' can be defined as a 'stable collection of practices and rules defining appropriate behaviour for specific groups of actors in specific situations' (March and Olsen 1998: 948). The institutions have an influence on actors within an organization not only by telling them what to do and how things should be done but also in 
specifying what kind of actions are unacceptable (Karlsson 2008: 41). In this context, the EU is the institution that outlines the appropriate behaviour for its member countries, and for candidate countries such as Turkey. According to the new institutionalist perspective, Turkey's counter-terrorism policies must be in line with EU standards. These two mechanisms have been applied to enlargement countries such as Poland, Hungary, Bulgaria, Romania, North Macedonia and Turkey. Within these, the EU impact has been analysed under the topics of democratization (Dimitrova and Pridham 2004; Freyburg and Richter 2010; Pridham 2002; Richter 2012; Sadurski 2004; Schimmelfennig et al. 2003), state-building (Keil 2013; Papadimitriou 2007), human rights (Arikan 2002; Iusmen 2012), ethnic minority rights (Kelley 2004; Tasch 2010; Vasilev 2011; Vermeersch 2002), conflict resolution (Tocci 2007; Tzifakis 2012; Woelk 2013), foreign policy (Mutlu 2011; M. Smith 2000; Van Westering 2000), asylum and immigration policy (Grabbe 2005; Novak 2013), monetary policy (Epstein 2008; Johnson 2008; Mattli 2004), political party systems (Vachudova 2008), and Justice and Home Affairs Policies (JHA) (Bakar 2011; Trauner 2009a). However, none of them has specifically focused on the counter-terrorism policy of a candidate state. As this analysis does focus on this policy, it therefore provides a novel perspective of the EU impact on Turkish counter-terrorism policies.

The remainder of this chapter is divided into four main sections. In the next section, the conditionality mechanism and how conditionality can be influential on Turkey's counter-terrorism policies will be explicated along with its variables. This will be followed by the section in which the socialization mechanism, its variables and its link with Turkish counter-terrorism policy will be highlighted. In the subsequent section, the instruments used by the EU to evaluate the extent of rule adoption in Turkey, and how the EU uses these instruments to implement the conditionality and socialization mechanisms, will be explained. Finally, in the last section, how internal and external policy actors are influential on the efficiency of these mechanisms will be discussed.

\section{CONDITIONALITY}

The conditionality mechanism generally applies in situations where an international organization promises rewards to target states, on the condition that they make certain policy adjustments, or instigate certain institutional changes (Schimmelfennig and Sedelmeier 2007: 88-9). The most well-known example of the mechanism at work is the International Monetary Fund's (IMF) use of conditionality. The IMF requires that member states implement certain economic policies in order to receive loans. In Europeanization studies, conditionality is considered as 'implementing a vast array of legislation and procedural rules in order to comply with EU standards' (Grabbe 2006: 207). The 
EU employs conditionality as a 'reinforcement strategy' towards candidate countries (Schimmelfennig and Sedelmeier 2004: 670). If a candidate country adopts the EU-promoted norms, it is rewarded with membership. If not, the EU suspends the entry of the candidate country to the Union. Conditionality is also a generic term that has been categorized as having two different forms. Hughes, Sasse and Gordon provide two categories of international conditionality: 'first-generation' and 'second-generation' conditionality. First-generation conditionality is based only on economic conditions, which are mostly related to IMF policy adjustments in third countries. Second-generation conditionality, used by the EU, arose after the collapse of the Soviet Union and combines both economic and political conditions (Hughes et al. 2005: 15-16). Similarly, Vachudova categorizes the EU's conditionality strategy as being comprised of an 'active leverage' and a 'passive leverage' strategy. The passive leverage strategy was in operation in the period before 1994 when the EU did not make a deliberate effort to influence the domestic policies of candidate countries. The democratization of target countries was not one of the EU's priorities (Vachudova 2005: 65). The active leverage strategy has been implemented from 1994 onwards since the EU developed its pre-accession process that includes extensive requirements for membership. The democratization of target countries then became one of the EU's primary goals (Vachudova 2005: 137).

Conditionality is categorized according to its rewarding ('positive') and punitive ('negative') features by Smith. Positive conditionality mechanisms are those where rewards are promised on the condition that certain requirements are fulfilled. Negative conditionality mechanisms are those that employ the 'reducing, suspending and terminating' of benefits if the target country fails to comply with the conditions laid down (K. Smith 1997: 4). For Lavenex and Uçarer, conditionality has two modalities: a 'domestic interest' modality and an 'external pressure' modality. In the former modality, EU policies are seen as opportunities to tackle existing internal problems, and domestic political actors' welcome EU conditionality. In the latter modality, where the adoption cost of transferring a policy to a target country is high, the conditions laid down are not welcomed by the target country, and so the conditions have to be imposed by making non-compliance itself costly for the target country (Lavenex and Uçarer 2004: 421). From Schimmelfennig and Sedelmeier's point of view, conditionality is comprised of 'democratic' and 'acquis communautaire' (acquis) conditionality. Democratic conditionality concerns the application of the founding principles of the EU, such as democracy, human rights, and the rule of law. Acquis conditionality first arose with the accession negotiations in which the EU began to monitor the adoption of specific rules by target countries (Schimmelfennig and Sedelmeier 2004: 677; 2007: 89). The acquis is the name of the common rules, standards, and policies of the EU. 
It is divided into chapters, each covering a specific policy area (e.g. Judiciary and Fundamental Rights (JFR) (Chapter 23) and JHA (Chapter 24)). Hughes, Sasse and Gordon have further argued that conditionality has both a 'formal' and an 'informal' dimension. Formal conditionality embodies publicly stated conditions, which consists of the Copenhagen criteria and acquis rules. Informal conditionality is concerned with the pressure and recommendations that European Commission members apply to their counterparts in target countries (Hughes et al. 2004: 526). Finally, Dyson has distinguished between 'soft' and 'hard' conditionality. 'Hard conditionality' arises in policy areas where EU rules are well-defined, and so there exists little room for manoeuvre in target countries. In such cases, the EU has been persistent in its attempt to impose those rules on target countries. 'Soft conditionality' arises in policy areas where the EU does not have well-defined rules. Although the EU has still attempted to impose more loosely-defined rules on target countries in some cases, it has done so less persistently (Dyson 2006: 15-16).

In view of these categories, this study principally concerns to what extent the EU liberal democratic conditions have been influential on Turkey's counter-terrorism policy. As Keohane (2008: 129-30) states, there is no defined EU counter-terrorism policy to be implemented in third countries. Furthermore, there is no chapter in the acquis allocated to counter-terrorism policy. Principles regulating liberal counter-terrorism policies for candidate countries were, however, defined at the Copenhagen European Council in 1993. The EU's political conditions, which involve ethnic rights and human rights, not only target the transformation of candidate countries' democracies, but they are also implicitly influential on candidate countries' counter-terrorism policies. For example, the abolition of the death penalty is seen as a significant reform and is one that the EU requires target counties to make in order to be considered as a true democracy. However, this issue has been closely linked with issues in the counter-terrorism debate. For example, the question has been raised in Turkey as to whether it is legitimate to impose the death penalty on Abdullah Ocalan, the captured leader of the PKK. Therefore, the link between the EU's liberal democratic norms and the counter-terrorism policies of Turkey require us to focus more on democratic conditionality, rather than the other conditionality types.

\section{Theorizing Conditionality}

The conditionality mechanism used by the EU is based on Rational Choice Institutionalism. According to this theoretical approach, the political actors are regarded as rational entities who voluntarily choose from the available alternatives on the basis of the future benefits they offer (Schimmelfennig and Sedelmeier 2005: 9). These political actors act on the 'logic of consequence' in 
which they maximize their own interest, power and welfare (March and Olsen 1998: 949). When these political actors are seeking alternative institutional engagement for their benefit, they may realize that their expectations can be achieved efficiently by being a member of a certain institution and, as such, they may be involved in a bargaining process with this institution. The desire to be part of that institution, and the contingencies of the bargaining process, will then serve as a constraint on their behaviour (Peters 1999: 44). The desired coordination between a political actor and an institution depends on the bargaining powers of the actors and the opportunities seized by them (March and Olsen 1998: 949). Therefore, institutions provide incentives for political actors to strengthen their bargaining power. If the political actors gain benefits from institutional membership, they abandon their inappropriate behaviour to receive those benefits (Peters 1999: 47). If the provided incentives do not offer significant benefits, however, the political actors will be reluctant to change their behaviour in line with the institution's rules. The institutions themselves also aim to maximize their benefits by creating an environment that has similar standards to the institution itself. Such an environment reduces external risks for the institution (Schimmelfennig 2012: 10). In order to accomplish this objective, members of the institution set some rules that structure behaviour. If the outside players wish to join the institution in order to maximize their benefits, they are obliged to adopt these rules. Setting such rules for prospective members protects the institution from instabilities spreading into the institution itself by contagion.

Turkey, considered as a rational political actor, has been seeking stable markets for exporting its goods since the early 1980s. The EU's unwavering export markets were very attractive to Turkish political actors compared with those in the Middle East (Birand 2005: 325). Therefore, ensuring integration into the EU was an important step for Turkey's economic development and prosperity. However, the EU has set a number of liberal democratic conditions to be met by any prospective EU member. The political cost of these conditions was high for Turkish political actors because Turkey was struggling at the time with the PKK. In order to combat the PKK, Turkey implemented heavy-handed counter-terrorism policies towards it, such as extrajudicial killings, village evacuations, banning Kurdish, and torturing PKK members and sympathizers. Adoption of the EU's liberal democratic norms would have involved granting ethnic rights to Kurds, which created fear in Turkish political actors that the demands of autonomy from the Kurds would increase and become legitimized. Furthermore, the required norms would have curbed the authority and immunity of the security forces in the struggle against terrorism. In these circumstances, Turkish political actors were forced to make a calculation balancing the benefits of EU membership with the adoption costs of EU-promoted norms on its counter-terrorism policies towards the PKK. 
When considering the EU requirement on Turkey to find a peaceful solution to PKK terrorism, Turkey's wish to maximize its own interests is not the only relevant issue. The EU's self-interest in protecting itself from the instabilities in Turkey is also relevant. Turkey's hard-line counter-terrorism policies towards the PKK exacerbated the tension in the south-eastern region of Turkey, rather than solving the Kurdish question. Rising instability in the region led many Kurds and others to seek asylum in Europe. Involvement of some of the Kurds in criminal acts in European countries raised concerns about Turkey's counter-terrorism policies and their consequences. Furthermore, without a peaceful solution to PKK terrorism, including Turkey in the EU was likely to lead to an internalization of Turkey's Kurdish problem in the EU itself. Therefore, the EU followed an active strategy towards Turkey, by reinforcing democratic reforms in order to transform Turkey's counter-terrorism policies. The conditionality mechanism was the main strategy employed to encourage Turkey to adopt EU-promoted liberal norms, such as human rights and ethnic minority rights, in return for granting membership to Turkey. The membership incentive offered by the EU is the most valuable incentive for Turkey. However, in order to increase its bargaining power and motivate Turkey to adopt EU rules, the EU has also provided technical and financial assistance to Turkey. In order to aid it in the adoption and implementation of the EU liberal democratic norms, different schemes have been employed to transfer 'know-how' and direct investment to Turkey.

Technical assistance has been offered to Turkey and other countries using two instruments: the Technical Assistance and Information Exchange Instrument (TAIEX) and the Twinning Projects instrument. These two direct forms of assistance have been influential on Central and Eastern European Countries (CEECs) in improving the quality of their public administration in terms of human resources, management skills and transparency (OECD 2011: 295). Under the TAIEX scheme, the EU supports candidate countries with short-term assistance, for example by training significant numbers of officials, and by offering guidance on the transposition of EU legislation (Commission of the European Communities 2013). The Twinning Projects instrument is used by the EU to develop candidate states' technical capabilities. These projects are designed to provide support to beneficiary countries in the implementation of EU acquis rules within priority areas decided by the EU Commission. The EU experts reside in the beneficiary country and the projects are carried out in a cooperative way between the member state's home administration and the corresponding ministry of the candidate state (Commission of the European Communities 2010a).

Although Rational Choice Institutionalism presents a general theoretical framework in which to understand the conditionality strategy, there are also other mediating factors that determine the efficiency of the EU's condition- 
ality strategy. So, in the next section, two independent variables, 'credibility of conditionality' and 'adoption costs', will be explained in detail in order to assess how EU conditionality can be efficient in transforming Turkey's counter-terrorism policies.

\section{Credibility of Conditionality}

To motivate candidate states, the EU uses rewards for the adoption of its rules and withholds the rewards in cases of non-compliance. EU membership is the key incentive for candidate states that inspires the governments to make reforms. The credibility of conditionality depends on the capabilities of the EU in fulfilling its promises. If the EU fulfils its promises, the credibility of conditionality increases, but if it does not, the credibility decreases (Schimmelfennig and Sedelmeier 2005: 13-16). The EU must be capable of withholding rewards in cases of non-compliance, and capable of delivering the rewards in cases of compliance (Schimmelfennig and Sedelmeier 2004: 673). Its capability must also be known by the target country (Sedelmeier 2011: 12), and trust between the EU and the target country must be established (Pridham 2007b: 464). Furthermore, the EU's credibility depends on its use of merit-based monitoring (Vachudova 2005: 112-20). If the EU's conditionality strategy is not credible, the target country can use this uncertainty to gain room for manoeuvre (Grabbe 2006: 192), or it can criticize the EU for its double standards (Tocci 2007: 24).

Inconsistency among the member countries in rewarding target countries reduces the credibility of its conditionality (Aybet 2006: 538; Baç 2008: 214-16). In addition, the EU's credibility suffers if there is any inconsistency between the Commission and the member states (Grabbe and Sedelmeier 2010: 382). Furthermore, if the EU does not set a definite deadline for administering the rewards it promises and makes unclear promises, this also reduces the credibility of conditionality (Lavenex and Uçarer 2004; Pridham 2007b: 459; Steunenberg and Dimitrova 2007). On the other hand, by not setting a definite deadline for administering rewards, the EU can increase the efficiency of conditionality. This is because candidate countries can be punished, or their reward can be administered by the EU, at any time during the negotiations. This motivates candidate counties to adopt norms in an ongoing manner (Anastasakis 2008: 368; Avery 2009: 263; Schimmelfennig and Scholtz 2008: 207; Steunenberg and Dimitrova 2007). The value of the reward also plays a role in determining the credibility of conditionality. Membership conditionality has the highest cost for the EU and is the highest reward for candidate countries (i.e. in comparison with technical and financial assistance). For example, the EU has made attempts at collaboration with Morocco and Algeria on issues of counter-terrorism (Wolff 2009a: 173; 2009b: 150). However, the EU has not been able to make progress because it has not offered either 
country a membership incentive (Hadfield 2009: 93-4). Admission of new members into the EU requires new infrastructure, and new members increase the heterogeneity of the Union. The decision-making process becomes more complicated with the addition of new members (Leuffen and Schimmelfennig 2007: 7).

In the changing relations between Turkey and the EU, the credibility of conditionality is considered to play a crucial role in the transformation of Turkish counter-terrorism policies towards the PKK. As repeatedly emphasized, violent PKK attacks towards civilians and the armed forces, and its secessionist motives to establish an independent state in south-eastern Turkey, generate turmoil in Turkish domestic politics. If the Turkish government downplays these attacks and motives, it may then be in a weak position and unable to accomplish its fundamental security duties. This is why the Turkish government has often employed hard-line counter-terrorism policies with the aim of eliminating the PKK and in order to retain its political power. In order to abandon such policies, there must be a tangible reward for Turkish political actors. EU membership is the most valuable incentive for Turkish politicians to give up their existing counter-terrorism policies, and convince the Turkish public, opposition parties and those in nationalist circles that it is in the country's best interest to do so. Therefore, having credible EU membership prospects is an important factor in changing Turkey's counter-terrorism policies in line with EU requirements.

\section{Adoption Costs}

The adoption cost of EU-promoted rules is another important factor in measuring the efficiency of conditionality. The adoption of EU-promoted norms upsets the domestic equilibrium in candidate states, which means that their existing/traditional policies conflict with the EU's liberal democratic policies. It, therefore, creates a political cost for candidate countries; otherwise the policies would be adopted without resistance (Schimmelfennig and Sedelmeier 2005: 16). In order to offset adoption costs, the EU provides motivational incentives to target countries. As many authors emphasize, EU membership is the most precious reward for many countries (Grabbe and Sedelmeier 2010: 390; Schimmelfennig 2007; Schimmelfennig et al. 2006: 54). However, the decisions of target states also depend on the size of domestic costs (Schimmelfennig et al. 2006: 52). There are several reasons given for there being high adoption costs. The reduction of state autonomy is one of the high adoption costs (Klievewer and Stivachtis 2007: 153). The political competition in the target country, which relies on ethno-nationalist representation, creates another high adoption cost for third countries (Džihić and Wieser 2011). If the liberal democratic norms of the EU affect the security and integrity of a state, 
this also increases the adoption costs for it (Schimmelfennig 2007: 130). In the area of counter-terrorism, which is related to national security and sovereignty, adoption costs are high for governments (Bakar 2011: 15). The leverage an external actor has upon such critical security issues could raise domestic opposition. The domestic opponents consider rule adoption as a weakening factor in the struggle against counter-terrorism. Furthermore, they can criticize the government for betrayal (Walker 2013: 229). Therefore, a low level of adoption cost is a necessary factor for the adoption of the EU-promoted liberal democratic norms.

Adopting the EU's liberal democratic norms, whilst engaging with the PKK, is costly for Turkey. State elitists, such as governing party representatives, higher-ranking army officers or senior Supreme Court members, and opposition parties, perceive the transposition of EU rules as a risk to domestic security. It is thought that adopting EU rules makes countering the PKK by military means impossible, and so leads to an escalation of PKK influence in the south-eastern region of Turkey. Furthermore, granting ethnic minority rights to Kurds is considered to increase the risk of a Kurdish state forming in the south-eastern part of Turkey. Therefore, aside from tangible incentives, events that reduce adoption costs for decision-makers in Turkey are needed in order to facilitate the adoption of EU-promoted norms. The unilateral ceasefire of the PKK, or the capture of PKK leader Abdullah Ocalan, are examples of such events.

\section{SOCIALIZATION}

Although conditionality is the dominant approach used to explain the interaction between Turkey and the EU, it does not always explain the changing patterns of political behaviour in Turkey. More specifically, it does not do so in the absence of membership prospects and with high adoption costs. Hence, another complementary mechanism is needed. To this end, the socialization mechanism counterbalances the weaknesses of the conditionality mechanism. The socialization mechanism is defined by Checkel as a process of adopting and internalizing the norms of a certain community, which is independent of the material incentives offered and sanctions imposed (Checkel 2005: 804). In the enlargement framework, the EU is considered as an agent that socializes third countries by promoting its norms. Correspondingly, the third countries are the agents socialized by the EU, because they come to believe EU norms are appropriate to solve their indigenous problems. Three logics have been used in conceptualizing socialization. In the first group, socialization is based on the 'logic of appropriateness', in which individual states learn from the community they identify with (Kubicek 2003: 6). A socialization agent, such as the EU, persuades, shames or teaches the target country to adopt appropriate 
norms and rules (Checkel 2005: 804; Risse and Sikkink 1999: 1-38). The norm diffusion occurs when the target country accepts that 'Good people do X' (Kubicek 2003: 6). According to the second group, the socializing agent and the socialized actor can engage with each other because the socializing agent offers material benefits to the socialized actor, and the socialized actor has domestic costs that it wishes to reduce. The EU transfers its community norms, values, and rules to improve its own security, welfare, and power. On the other hand, the target country adopts community rules to increase its political utility. In that sense, neither the EU nor the target country engage in socialization due to the appropriateness of the community rules, but rather due to the 'logic of consequence' (Schimmelfennig et al. 2006: 18-19). This type of norm diffusion can be understood as 'Do X to get Y' (Kubicek 2003: 6). There is also another socialization process that combines both logics, which is called the 'Spiral Model'. Governments are not the only actors in socialization processes. There are also norm entrepreneurs and epistemic communities, and, in addition, advocacy networks also play a crucial role. When socialization occurs, the government of a target country at first uses the logic of consequence and resists adopting community rules to protect its power. However, the moral discourse, initiated by mediating domestic actors (such as norm entrepreneurs), breaks down this resistance. So, over time and due to increasing pressure, they end up adopting the community rules as a result of the 'logic of appropriateness' (Risse and Sikkink 1999: 16).

In view of three logics of socialization, this study utilizes the 'logic of appropriateness' in understanding social transformation in Turkish counter-terrorism policy. According to this form of socialization, adoption of the EU rules by Turkish political actors is based on the appropriateness of the norms, rather than on cost-benefit calculations made by them. The EU's political conditions promoting human rights and ethnic minority rights are transposed by Turkish political actors because consideration of these norms can help to find a peaceful solution to PKK terrorism. The theoretical framework for socialization will be explained in the next section in order to understand how socialization leads to the transformation of Turkey's counter-terrorism policies in line with the EU-promoted norms.

\section{Theorizing Socialization}

The EU's socialization mechanism is based on sociological institutionalism. This theoretical approach is built on the 'logic of appropriateness', in which political actors follow the rules of a certain environment associated with identities, values, and norms. According to sociological institutionalism, members of an institution engage in appropriate actions depending on their previous experiences. These actions provide stability to the institution and are 
good for the individuals themselves (Peters 1999: 103-106). Social interaction between political actors involves learning and, as a consequence of what is learnt, their political behaviour changes (Checkel 1999: 547). Material benefits provided by the socializing institution are not the main cause of changing political behaviour in this model. If the socialized actors are convinced that the promoted rules of the socializing institution are legitimate and appropriate, they adopt the norms of the institution (March and Olsen 1998: 951-2). If not, they carry on with their existing behaviour. As a normative power, the EU promotes liberal democratic values such as the rule of law, and the protection of human and ethnic minority rights, in its neighbourhood (Manners 2006). When countries in the vicinity of the EU consider these norms to be appropriate to solve their internal problems, they then adopt them autonomously. In such circumstances, no disputes arise between the socializing and socialized actors. Instead, the norms are adopted through a social learning process (Beichelt 2012: 8). In view of Turkey's counter-terrorism policies, the EU-promoted liberal democratic norms offer a potentially appropriate way to solve PKK terrorism peacefully. For example, democratic control over armed forces obliges security officers to be more accountable for their actions during counter-terrorism operations. Also, adherence to human rights limits the abuse of coercive power by security forces against terrorist suspects. In addition, providing public services in the Kurdish language (e.g. by translating municipal documents into Kurdish) integrates Kurdish citizens into society and protects them from PKK manipulation. Therefore, Turkish political actors might adopt these norms if they come to accept that they are an appropriate solution to existing terrorism problems. Furthermore, they may conform to these norms due to thinking that Turkish citizens deserve to have democratic standards similar to those enjoyed by EU citizens.

Although sociological institutionalism constitutes a theoretical framework for understanding the socialization strategy, there are a few mediating factors, which are influential on the efficiency of the EU's socialization strategy. In the next section, two independent variables of socialization, the 'legitimacy of EU requirements' and 'domestic resonance', will be explained in order to emphasize how the EU's socialization strategy can be efficient in altering Turkey's counter-terrorism policy towards the PKK.

\section{The Legitimacy of the EU Requirements}

According to Franck, legitimacy means 'the quality of a rule, or a system of rules, or a process for making or interpreting rules that pull both the rule makers and those addressed by the rules toward voluntary compliance' (Franck 1992: 50). In line with this definition, the quality of institutional requirements is further increased if these requirements are respected both by institutions and 
individuals. In terms of the EU norm diffusion framework, the EU demands on third countries gain legitimacy if these demands are respected by the EU (and its member countries) as well as by third countries. In order to improve the legitimacy of the EU requirements, these demands should be based on factors such as clarity, consistency, and ownership of the EU (Schimmelfennig and Sedelmeier 2004: 676). Setting clearly defined requirements is one of the determinants of the efficiency of the socialization strategy. If the norms proposed by the EU are clearly defined, the likelihood of rule adoption increases in target countries (Schimmelfennig and Sedelmeier 2005: 13). The clarity in the requirements reduces the risks of political management in third countries because domestic political actors know what the EU is demanding, and what they should do in order to meet those demands (Tocci 2007: 25).

The clarity of EU requirements is important for any country struggling with terrorism, and at the same time trying to become a member of the EU. If such countries are subject to severe EU criticism, they will naturally expect the EU to suggest a concrete alternative strategy. If there is no such strategy in the EU structure, the EU becomes a power that tells others in general terms what to do but does not have a specific solution to propose. In the absence of clear guidelines on how to act, the legitimacy of the EU requirements on counter-terrorism policy will decrease. The candidate countries will interpret the EU requirements widely for their own interests, and, in the end, the EU-promoted norms will not be adopted in an appropriate way.

Along with clarity, consistency increases the legitimacy of the EU requirements. In order to be consistent, each member of the EU and each of its institutions should endorse the requirements that the EU lays down (Schimmelfennig and Sedelmeier 2005: 18). Non-member countries may reasonably object to having to adopt an EU-promoted norm if there is disagreement about it within the EU (Sedelmeier 2011: 11).

Some EU countries have had real experiences of domestic terrorism, whilst others have not. For example, the UK, France, Spain, Germany and Italy, have experienced relatively high levels of terrorism in comparison with the other EU countries (Rees and Aldrich 2005: 910). As such, different EU countries have different threat perceptions regarding the possibility of terrorist attacks. Because of this diversity amongst the member countries, there has been a negative consequence when it comes to norm promotion in third countries. Those EU countries that have faced terrorism themselves tend to be more sympathetic with the hard-line counter-terrorist approach that candidate countries have used. However, those countries that have not faced a terror problem in their territory tend to pursue a more rigid approach towards these countries. A lack of unanimity amongst member states reduces the legitimacy of EU requirements.

The 'ownership' issue is another factor that is influential on the legitimacy of the EU requirements. If the EU can create an impression that the require- 
ments have been formulated by the EU itself (i.e. that it 'owns' them), this may lead to an increase in the legitimacy of the EU demands (Schimmelfennig and Sedelmeier 2005: 19). Furthermore, if the EU requirements are based on the EU's legal structure and overlap with other requirements laid down by other international organizations, then the legitimacy of the EU requirements increases in target countries (Freyburg et al. 2009: 926). However, in some policy areas, the EU may lack clear rules of their own, or its rules may conflict with those of other international organizations (Schimmelfennig and Sedelmeier 2005: 19). In such cases, the legitimacy of the EU requirements is undermined because of cross-socialization. In order to promote liberal counter-terrorism policies, the EU uses both the norms of other international organizations and its own norms, to transform the counter-terrorism policies of candidate countries. For instance, the EU utilizes the European Court of Human Rights (ECtHR) litigations to emphasize its concerns about human rights violations that relate to counter-terrorism policies in candidate states. Alternatively, the EU evaluates the progress of the candidate states' counter-terrorism policies by relying on the OSCE recommendations, which relate to ethnic minority rights. If these institutions' monitoring mechanisms and legal frameworks overlap with the EU demands, the legitimacy of the EU requirements increases. However, where the EU lacks its own rules and monitoring mechanisms and relies almost solely on the rules and mechanisms of other institutions, the EU itself will be less influential in altering the political behaviour of candidate countries.

In EU-Turkey relations, the legitimacy of the EU demands is an important factor in ensuring that Turkish political actors adopt the EU-promoted norms to change their counter-terrorism policies. In consideration of the high adoption costs that terrorist attacks impose on policy transformation in Turkey, Turkish decision-makers pay great attention to whether the EU demands are clear to follow, whether they are applied consistently, and whether they are owned solely by the EU or shared with other international organizations. If the EU requirements lack clarity, Turkish political actors may take advantage of their ambiguity, and continue to implement their existing counter-terrorism policies in order to avoid conflict with domestic opposition. Similarly, if the EU demands are inconsistent, there is no convincing reason for the Turkish political elite to transpose EU-promoted norms because other EU members have not themselves adopted them. Furthermore, Turkey has been monitored not only by the EU, but also by other international organizations (such as the UN, the CoE, the ECtHR, and the OSCE). If the requirements of the other international organizations are more dominant than the EU's, then this decreases the latter's legitimacy, which may lead to the Turkish political elite paying less attention to them than they do to the former. However, if the EU's demands overlap with the requirements of other international organizations, 
this can increase the legitimacy of the EU's demands, which increases the efficiency of the EU's socialization mechanism.

\section{Domestic Resonance}

The adoption of the EU-promoted norms also depends on the attitude of domestic political actors and the general public. Whether a non-member state complies with the appropriate rules depends on how these rules are perceived by the domestic political elite and the public. There are two things that increase domestic resonance. First, domestic resonance is increased if domestic political actors are open to innovative ideas regarding how to solve their domestic problems. Second, it is increased if those ideas are accepted as being legitimate by the general public, i.e. if they chime with the public's existing cultural and political beliefs (Schimmelfennig and Sedelmeier 2005: 20). In relation to the first point, in the absence of domestic policy prescriptions in a problematic area, or where the EU-promoted norms are perceived as being better than the existing domestic rules, domestic political actors are likely to be more open to rule adoption. Unless domestic political actors are open in this way, rule adoption is unlikely to occur in the target country. Existing policies will be stubbornly applied without proper consideration of their failures, and without proper consideration of the available alternatives. In relation to the second point, a lack of domestic legitimacy can stem from the tendency of public administrative bodies to reflect the existing cultural and political beliefs of the general public. If those existing beliefs conflict with the new policies, the public administrative bodies tend to stick to policies based on historical legacies and traditional habits that do not conflict in this way (Pridham 2007a: 248). In so doing, they refrain from adopting the EU-promoted norms in order not to damage national political culture (Schimmelfennig and Sedelmeier 2005: 20).

Applied to Turkey, in order for there to be an effective transformation of Turkey's counter-terrorism policies, there should be openness amongst the Turkish political actors both in politics and public administration to adopt innovative EU-promoted norms. Turkish politicians, judiciary, senior security officials, and the general public must, therefore, realize that the existing hard-line counter-terrorism policies have failed to solve the PKK problem. In addition, they must also come to believe that the EU-promoted liberal democratic norms should be considered as the best alternative policy option. However, in dealing with such a sensitive security issue, the adoption of EU-promoted norms may be seen as a threat to internal security and territorial integrity. Furthermore, fear of Kurdish territorial separation may lead to there being a consensus that existing hard-line counter-terrorism policies are legitimate and the most appropriate way to deal with the PKK. This consensual legitimacy may also play 
into the hands of supporters of hard-line counter-terrorism policies in public administration. Therefore, the Turkish political elite, judiciary, and security bureaucrats may be reluctant to abandon their traditional understanding of how to deal with counter-terrorism. Moreover, these decision-makers may not be aware that the EU-promoted liberal democratic norms can be useful in diminishing the manipulation of Kurdish citizens by the PKK.

\section{THE TOOLS EVALUATING ADOPTION OF EU-PROMOTED NORMS}

In order to evaluate the accession progress of candidate states, the EU Commission has played a 'gatekeeper' role. It is this institution that determines whether a candidate state passes to another stage in the process of accession (Grabbe 2001: 1019-20; 2002: 256). To follow this progress, the EU employs five instruments in order to apply the conditionality and socialization mechanisms. First, the EU uses 'demarches' to condemn candidate states in cases where their practices are undemocratic (e.g. where abuses of human and ethnic minority rights take place). Any criticism made by the EU has a powerful impact on democratic debates in candidate states because the EU questions the performance of the indigenous government openly (Grabbe 2001: 1021). The EU's negative assessment may undermine the success of the government in the eyes of its electorate (Vachudova 2005: 127). On the other hand, gaining EU approval legitimizes the political choices of the domestic political actors (Grabbe 2001: 1021). Alternatively, in some circumstances, politicians can take advantage of demarches to mobilize their supporters during the election campaign. Second, 'opinions' are another tool used by the EU to evaluate the progress of candidate states. In July 1997, the European Commission published its Opinions by assessing each candidate state in the light of the Copenhagen political criteria and the ability to apply the acquis. Moreover, it made predictions about whether candidate states are ready for membership (Vachudova 2005: 128). Third, progression reports are one of the important instruments used by the EU to assess the progression of candidate states. The progression reports were published for the first time in 1998 and have been subsequently published yearly and include an assessment of every candidate state until they become members of the Union (Vachudova 2005: 129). These reports include different sections in which the European Commission evaluates the progression of each candidate states under the categories: 'Copenhagen Political Criteria', 'Economic Criteria', the 'Ability to Assume the Obligation of Membership', 'Common Foreign and Security Policy', amongst many others (Usul 2011: 62). As mentioned earlier (see the section on conditionality), there is no chapter on counter-terrorism in acquis. Consequently, there is no specific section reserved only for the evaluation of the counter-terrorism policies 
of candidate states in the progression reports. However, counter-terrorism policy failures are evaluated under the 'Copenhagen Political Criteria' or the 'Justice and Home Affairs' sections. Fourth, the accession partnership and the national programmes are two other tools designed to promote rule adoption. The accession partnership provides a clear 'work plan' to candidate countries, in which the rules and regulations they must adopt are outlined (Grabbe 2001: 1022; Vachudova 2005: 130). Furthermore, the European Commission sets a time frame in each accession partnership (such as mid-term and long-term) to indicate which reforms should be a priority for candidate countries. In response to this, candidate countries prepare a national programme, which consists of reforms that the government intends to fulfil. Promised reforms are also categorized under mid-term and long-term priorities (Vachudova 2005: 130). The national programmes are also an indication that a candidate country's government is aware of the EU requirements and the government's responsibilities. Finally, screening and negotiations are other important tools in evaluating progression towards accession. Screening involves the process of checking whether the domestic laws are compatible with the acquis. It is carried out collectively by the Commission and candidate states. After the screening process, the EU and the candidate state enter into negotiations based on each individual chapter of the acquis, and candidate states must prove that they have made progress in the adoption and implementation of the rules given in each of its chapters (Usul 2011: 63; Vachudova 2005: 130-32).

\section{POLICY ACTORS}

In order to understand policy changes using the conditionality and socialization mechanisms, the political actors who have a direct or implicit impact on Turkey's counter-terrorism policy should be taken into consideration. These actors play a significant role in the transformation of Turkey's counter-terrorism policies in line with EU rules. They sometimes aid norm diffusion in Turkey and sometimes hinder it. In this respect, this section will focus on these policy entrepreneurs. They will be categorized as falling into two major groups: internal and external actors.

\section{Internal Actors}

In order to understand the transformation of Turkey's counter-terrorism policies, it is important to understand the perceptions of its internal political actors. If the majority of these actors see the EU-promoted norms as being appropriate and beneficial for Turkey, norm diffusion is likely to occur. On the other hand, if the majority of the internal actors are against the reforms, it is not likely to occur. There are two groups of internal actors in Turkey who are influential in 
the EU accession process. The first group is known as the 'pro-EU coalition/ circle', and its members support the adoption of EU norms (Eylemer and Tas 2007; Onis 2003: 20). This group is aware of the dangers of terrorism and seek democratic ways to deal with it and to prevent the threat of Kurdish separation. According to this group, the adoption of the EU-promoted norms can be helpful in finding a peaceful solution of PKK terrorism. With the use of the EU rules, these policy entrepreneurs also aim to increase their influence in the political system (Eylemer and Tas 2007: 570; Schimmelfennig and Sedelmeier 2005: 11).

The second group are known as 'the veto players' and its members oppose the adoption of EU norms (Schimmelfennig and Sedelmeier 2004; Young and Dugan 2011). According to Tsebelis (2002: 19), veto players are individual or collective actors and securing their agreement is a necessary condition of changing the status quo. The change in the status quo requires the unanimous agreement of all the veto players. According to this group, the PKK's terrorist activities can be solved only by military means, and this group defends the adoption of hardline counter-terrorism legislation. The adoption of EU rules in the area of a human and ethnic minority is thought by this group to weaken Turkey in its struggle against the PKK, and so the rules are considered a threat to territorial integrity. Liberal laws are seen as a concession to terrorists and their supporters. Security-based concerns are seen by this group as being more important than the possible benefits of EU membership, and the adoption of the liberal values of Europe.

Nevertheless, the distinction between the pro-EU coalition and the veto players is not stable. The political stance of these actors towards the adoption of EU-promoted norms has changed during the EU accession process. The political actors who oppose EU reforms at one time may at other times position themselves with reformist groups, and so may, at those times, support the adoption of EU-promoted norms. Contrarily, some of those who are generally placed in the reformist camp may at times ally themselves with veto players and challenge EU reforms. In this respect, rather than focusing on these political actors according to the aforementioned grouping, relying on four groups of political actors can reveal much about the political stance of domestic policy entrepreneurs.

The first group is the Turkish governments, who are the primary political actors in policymaking in Turkey. All legislative actions and institution-building initiatives put in place to protect human rights are under the responsibility of the government of the time. There are three ministries in the government which are relevant in this discussion. The first two are the Ministry of the Interior, and the Ministry of Defence and they deal with counter-terrorism. The third is the Ministry of Foreign Affairs, responsible for negotiating with the EU. But each of these ministries is responsible to the government, and so, therefore, 
the government's decision is binding on each of these ministries and their subsidiary organs.

The second group is the Turkish Army, which is the leading security actor in the struggle with the PKK. Since the military coup attempt in 2016, the military is legally and institutionally responsible to the government. However, prior to this event, it has had autonomy on security matters and has not been accountable in any substantial sense to any civilian government since the 1960s (Greenwood 2005; Karaosmanoglu and Kibaroglu 2002). In this respect, the EU requirements, such as the requirement to increase the accountability of security forces, makes the Turkish Army an important internal political actor in the norm diffusion process, because if the EU rules are adopted, the army will lose its autonomy and impunity, a result it wishes to resist.

The third group is the judiciary. It is another internal actor that shapes the counter-terrorism policy of Turkey. The court decisions regarding terror suspects are not only subject to EU monitoring but also ECtHR decisions. If the judiciary's decisions conflict with ECtHR litigation, then this creates a problem between Turkey and the EU and necessitates further domestic legislative changes. It is therefore important to understand the position of the judiciary towards the EU requirements.

The fourth group is the general public, who are implicitly influential on Turkish counter-terrorism policies. Public opinion is an important determinant of whether Turkish governments are able to adopt the EU-required norms. If public opinion carries electoral risks for the government (e.g. because of a reduction in its popularity), the government will be reluctant to adopt the EU norms and will shy away from EU-based initiatives. On the hand, strong public support makes it easy for the government to adopt EU norms. In this respect, public opinion towards the EU-required norms should be taken into consideration in order to determine which norm diffusion mechanism is influential in Turkey.

\section{External Actors}

The external actors are another political group who are influential on policy adjustments in Turkey. The EU is seen as the major external policy actor influential on the transformation of Turkish counter-terrorism policies. However, there are also three other external policy actors who share regulations and recommendations with the EU in the area of counter-terrorism. That the influence of these actors is considered is important when measuring the legitimacy of the EU requirement in Turkey. When the EU's demands overlap with other international organizations, their legitimacy is increased.

The first of these external political actors is the CoE and its subsidiary institutions (such as the ECtHR, the European Committee for the Prevention 
of Torture (CPT), and the Venice Commission of the Council of Europe (VCCE)). The EU screens Turkey's human rights record by observing the ECtHR rulings, the CPT reports, and its cooperation with VCCE. Along with these instruments, the EU monitors compensation payments to those Turkish citizens identified as victims in the ECtHR rulings. The EU supports legislative changes that are made in conformance with the ECtHR litigations, and the CPT reports.

The second external policy actor contributing to legal Turkish counter-terrorism policy is the UN. The EU promotes the ratification of the UN conventions on terrorism to its member states and the third countries (European Union 2001: 7-8). Furthermore, the EU closely follows whether candidate states have adhered to UN protocols with regard to human and ethnic minority rights (Commission of the European Communities 2003: 110-19). Ratifying these UN rules is in itself a requirement that is laid down by the EU on candidate countries.

The third external policy actor is OSCE. Although the OSCE has a limited capacity to play an active role in fighting terrorism, its recommendations regarding public awareness and legal assistance are used by the EU to address problems in candidate states (Tardy 2004: 131). For example, the expertise and political dialogue of the OSCE High Commissioner on National Minorities (HCNM) guides the EU authorities when evaluating ethnic-based conflicts in candidate states (Kelley 2004: 17).

\section{CONCLUSION}

As explicated in the previous sections, conditionality and socialization are two prominent mechanisms that are considered when explaining the EU influence on Turkey's counter-terrorism policy towards the PKK. Why these two mechanisms are the most appropriate in dealing with EU-Turkey relations is related to Turkey's candidate status. Even though these mechanisms have been used for the CEECs, the Western Balkans and Turkey to explain the EU influence on domestic policy adjustments, they are employed for the first time here to examine a candidate state's counter-terrorism policy. Relying on just one of these mechanisms alone may be insufficient to explain the EU influence on Turkey. Using the conditionality mechanism alone may be insufficient because it appears that norm diffusion has occurred in Turkey even in the absence of concrete incentives. For this reason, it is necessary to also consider the socialization mechanism. Using the socialization mechanism alone, on the other hand, ignores the fact that when there are concrete incentives, norm diffusion is easier to secure. So, it is necessary to consider both mechanisms. In this regard, it is possible to build a 'bridge' between the two mechanisms by showing how they can both be operative (Jupille et al. 2003: 17-19). 
According to the conditionality mechanism, in the context of counter-terrorism, the likelihood of rule adoption increases if the EU provides a clear membership prospect to candidate countries, and there is a low level of the terrorist threat. In line with this proposition, Turkey is regarded as a rational political actor, which calculates the material benefits of EU membership and the costs of transforming its counter-terrorism policies. If the value of being an EU member is considered to be higher than the domestic political cost of changing counter-terrorism policies towards the PKK, Turkey is expected to adopt EU-promoted norms. However, in the absence of a clear membership prospect and high levels of terrorist violence, the likelihood of rule adoption in Turkey decreases. However, according to the socialization mechanism, in the context of counter-terrorism, rule adoption will be most effective if domestic political actors consider the EU requirements to be legitimate, and they are open-minded about adopting the EU-promoted norms. In this respect, Turkey, as a socialized agent, adopts the EU-promoted norms because EU norms are an appropriate way of solving its PKK problem in a peaceful way. If Turkish political actors see the EU requirements as being legitimate and appropriate, they are expected to adopt EU-promoted norms. Nevertheless, if the EU requirements are not seen to be legitimate, and Turkish political actors are reluctant to change the existing policy, rule adoption will be unsuccessful. In view of these arguments, the measurement of all variables can be schematized as follows in Table 1.1. 


\section{Table $1.1 \quad$ Variables and measurement parameters}

\begin{tabular}{|c|c|c|}
\hline & \multicolumn{2}{|c|}{ Measurement parameters } \\
\hline Variables & Low & High \\
\hline $\begin{array}{l}\text { Credibility of } \\
\text { conditionality }\end{array}$ & $\begin{array}{l}\text { - Uncertain membership prospect } \\
\text { - Lack of sanctions } \\
\text { - Uncertain rewards } \\
\text { - Double standard }\end{array}$ & $\begin{array}{l}\text { - Definite membership prospect } \\
\text { - Robust sanctions } \\
\text { - Certain rewards } \\
\text { - Uniform standard }\end{array}$ \\
\hline Adoption costs & $\begin{array}{c}\text { - Reduction in fatalities } \\
\text { - Ceasefire } \\
\text { - Winning elections } \\
\text { - Liberal tendency in government policies }\end{array}$ & $\begin{array}{l}\text { - Increase in fatalities } \\
\text { - Intense conflict } \\
\text { - Losing elections } \\
\text { - Illiberal tendency in } \\
\text { government policies }\end{array}$ \\
\hline $\begin{array}{l}\text { The legitimacy of the } \\
\text { EU requirements }\end{array}$ & $\begin{array}{c}\text { • Ambiguity } \\
\text { • Inconsistency } \\
\bullet \text { Ownership problem } \\
\text { (The requirements of other international } \\
\text { organizations are taken extremely seriously) }\end{array}$ & $\begin{array}{c}\text { - Clarity } \\
\qquad \text { Consistency } \\
\text { - Overlapping demands with } \\
\text { other international organizations }\end{array}$ \\
\hline Domestic resonance & $\begin{array}{c}\text { - Disapproval of EU norms by domestic } \\
\text { political actors (government-army-judiciary- } \\
\text { public opinion) }\end{array}$ & $\begin{array}{l}\text { - Approval of EU norms by } \\
\text { domestic political actors } \\
\text { (government-army-judiciary- } \\
\text { public opinion) }\end{array}$ \\
\hline $\begin{array}{l}\text { Adoption of EU- } \\
\text { promoted norms }\end{array}$ & $\begin{array}{l}\text { - Ignoring or slightly fulfilling EU-promoted } \\
\text { norms }\end{array}$ & $\begin{array}{l}\text { - Full codification of EU- } \\
\text { promoted norms or with little } \\
\text { exception }\end{array}$ \\
\hline
\end{tabular}

